\title{
Development of Airway Allergic Diseases and Immunotherapy in Children
}

\author{
Joon Kon Kim, Seong Il Kang ${ }^{2}$, and Dae Woo Kim ${ }^{1}$ iD \\ ${ }^{I}$ Department of Otorhinolaryngology-Head and Neck Surgery, Boramae Medical Center, Seoul National University College of Medicine, \\ Seoul, Korea; ${ }^{2}$ Department of Otorhinolaryngology-Head and Neck Surgery, Sheikh Khalifa Specialty Hospital, Ras Al Khaimah, United \\ Arab Emirates
}

\section{소아 알레르기 질환의 발생과 면역치료}

\author{
김준곤 ${ }^{1} \cdot$ 강성일 $^{2} \cdot$ 김대우 $^{1}$ \\ 서울대학교 의과대학 보라매병원 이비인후과학교실 ${ }^{1}$, 아랍에미레이트 세이크 칼리파 병원 ${ }^{2}$
}

\author{
Received April 3, 2019 \\ Revised May 3,2019 \\ Accepted May 7, 2019 \\ Address for correspondence \\ Dae Woo Kim, MD, PhD \\ Department of Otorhinolaryngology- \\ Head and Neck Surgery, \\ Boramae Medical Center, \\ Seoul National University \\ College of Medicine, \\ 20 Boramae-ro 5-gil, Dongjak-gu, \\ Seoul 07061, Korea \\ Tel $+82-2-870-2446$ \\ Fax $+82-2-831-2826$ \\ E-mail kicubi@daum.net
}

\begin{abstract}
Allergic march is a part of a phase that occurs in a series of continuous steps in disease of pediatric patients, which proceeds from atopic dermatitis to asthma, and from asthma to allergic rhinitis. Recently, several hypotheses have been raised to explain the allergic march. Among them, the study of the hygiene theory related to microbiota, and the study on the role of innate cytokines which occurs in skin barrier damage are attracting attentions. If the interaction between the microbiota and the immune system occurs improperly, the activity of the regulatory $\mathrm{T}$ cell becomes insufficient and the immune-regulatory function is reduced, resulting in allergic diseases. Because of the skin barrier disruption, the innate cytokines are activated, thus resulting in Th2 inflammation reaction being increased. Considering this pathogenesis, blocking the linkage to pathogens is regarded to play an important role in preventing and treating allergic march. Korean J Otorhinolaryngol-Head Neck Surg 2019;62(5):261-9
\end{abstract}

\section{서 론}

알레르기 행진은 소아 알레르기 질환 환자에서 아토피 피 부염으로부터 천식으로, 천식에서 다시 알레르기 비염으로 질 병이 진행하는 과정을 나타내는 용어이다. 아토피 피부염이나 천식과 관련되어 있는 알레르기 비염 환자의 경우 증상이 더 심하며, 치료에 잘 듣지 않는 불응성 비염의 양상을 띠는 경 우가 많아 임상적으로 중요성을 띤다. 이러한 불응성 비염은 복잡하고, 여러 가지 기전이 복합적으로 작용하여 증상을 나 타내기 때문에 단순한 방법으로는 치료하기가 쉽지 않다. 따 라서 질병의 발생 기전을 잘 이해하고 그에 맞는 개별화된 치 료가 필요하다. 최근 알레르기 행진을 설명하기 위해 여러 가

This is an Open Access article distributed under the terms of the Creative Commons Attribution Non-Commercial License (https://creativecommons.org/licenses/by-nc/4.0) which permits unrestricted non-commercial use, distribution, and reproduction in any medium, provided the original work is properly cited.
설이 제기되고 있는데 그중에서도 미생물군(microbiota)과 관련된 위생 가설(hygiene theory)과 피부 장벽 손상에 의해 발생하는 선천성 사이토카인의 역할에 대한 연구가 주목받 고 있다. 저자들은 이번 종설을 통해서 기도 알레르기 질환의 발생 기전을 미생물군과 선천성 사이토카인의 관점에서 소개 하고, 이러한 발병 기전을 차단하는 생물학적인 치료인 면역 치료와 단일클론항체(monoclonal anti-body)에 대해 설명해 보고자 한다.

\section{본 론}

알레르기 발생 기전

위생 가설에 대한 새로운 시각: 인간 역학 연구

Strachan ${ }^{1)}$ 이 형제가 많을수록 알레르기 질환이 감소한다는 
점을 토대로 위생 가설을 발표한 이후, 어린 시기에 다양한 환 경에 노출되는 것이 기도 알레르기 질환에 영향을 준다는 사 실이 널리 알려져 있다. 최근까지 보고된 환경적 요인과 알레 르기 질환과의 관계를 표로 정리해 보았다(Table 1).

다양한 환경적인 요인이 알레르기 질환의 발병에 영향을 미치는데, 그 영향은 노출 시기에 따라 달라진다. 출생 코호트 를 통한 천식의 위험도 조사를 시행한 연구에서 1 세 이전에 바 퀴벌레, 쥐, 고양이 특이 항원과 Firmicutes, Bacteriodetes 균 종에 많이 노출이 된 아이들은 알레르기 감작이 적었으나, 3세 이후에 같은 항원에 노출되게 되면 알레르기 감작과 관련된 다고 보고를 하였다. ${ }^{2)}$ 성인에서의 내독소(endotoxin)에 대한 노출은 천식을 발생시키는 위험 요소가 되는 반면,3) 소아에서 는 천식 발생을 예방하는 효과를 가진다. 농촌과 농촌 외 지역 의 내독소에 대한 노출 비교는 농촌지역에서 아토피 감작이 더 많다고 보고를 하였다. 그리고 학동기(school age) 이전의 내독소 노출과 비교하였을 때, 학동기의 노출이 아토피에 대 한 위험 요소를 감소시켰다.) 즉, 지역적 차이와 항원 노출 시 기가 알레르기 질환의 발생에 영향을 준다고 볼 수 있다. 환경 적인 요인은 특정한 시기에 인체와 상호작용을 통해 알레르 기 질환을 예방하거나 발생시키며, 특히 면역 관용(immune tolerance)을 얻기 위한 기회의 시기(window of opportunity) 는 생후 1 년 내외의 신생아 시기라고 생각한다. 가족의 규모와 알레르기 질환을 살펴보면, 알레르기 질환 유병률과는 반비례 하고, 알레르기 증상의 정도는 비례한다고 보고를 하였다. ${ }^{5)}$ 알레르기 질환과 보육시설의 비교 연구를 살펴본 결과, 아토 피 병력이 있는 부모 중 어머니(maternal)가 천식이 없는 경우 보육 시설(day care attendance) 양육은 자녀들의 생후 1년과
6세 이후의 천식 발병을 감소시키는 것으로 나타났다. 단, 어 머니가 천식이 있는 경우는 천식 발병 감소에 유의한 결과를 나타내지 못하는 것으로 보고를 하였다. ${ }^{6}$ 반려동물과 알레르 기 감작을 연구한 결과, 생후 1년에 2마리 이상의 반려동물(개, 고양이)을 기를 경우 아동기(childhood)에 알레르기 감작이 감소되었다.) 아래의 연구들은 알레르기 질환과 역의 상관관 계를 갖는 것으로 나타났는데, 식기세척기와 알레르기 질환 을 연구한 논문에서, 식기세척기는 손 세척보다 알레르기 항 원에 노출이 더 증가되는 것으로 보고를 하였다. ${ }^{8}$ 출생 전/후 항생제를 사용한 결과, 천식의 발생은 증가하였다. ${ }^{9}$ 제왕절개 분만 출생 아이는 자연 분만 출생 아이와 비교해 천식의 발생 이 증가하는 것으로 보고를 하였다. ${ }^{10}$ 개인 및 가정 청결도와 알레르기 질환 발병의 연관성을 연구한 논문에서는 두 가지 사이의 관련성은 없다고 보고를 하였다.11) 모유 수유와 알레 르기 질환의 연관성을 연구한 논문은 지금까지 많았다. 현재 긍정적인 효과와 부정적인 효과를 나타내는 연구가 각각 보 고되고 있어서 앞으로 연구가 지속되어야 할 것으로 보인다.

\section{미생물군(microbiota)}

미생물군은 생명체 내에 있는 전체의 미생물군을 의미하 는 단어로 생재균, 공생균, 기생균 모두가 이에 해당한다. 인 간 몸에 사는 미생물의 유전정보 전체를 의미하는 미생물군 유전체(microbiome)도 비슷한 의미로 사용된다. 미생물군은 인체 점막에 군집을 형성하여 인체와 다양한 신호를 주고받 으며 면역반응을 일으킨다. 다양한 환경적인 노출이 출생 순 간부터 혹은 그 이전부터 미생물군의 구성에 영향을 준다. 제 왕절개를 통하여 태어난 아이는 질식분만을 통해 태어난 아

Table 1. Environmental exposure in early life and development of allergic disease

\begin{tabular}{|c|c|c|c|}
\hline & Exposure & Implication & Reference \\
\hline \multirow[t]{7}{*}{ Favorable } & Farming house & $\begin{array}{l}\text { - Endotoxin: Inverse association with hay fever, atopic sensation, } \\
\text { atopic wheeze }\end{array}$ & 4) \\
\hline & & $\begin{array}{l}\text { - Exposed subject's atopic status, the timing of the exposure: } \\
\text { determine positive/negative effects }\end{array}$ & \\
\hline & Family size (siblings) & - Prevalence: inverse association & 5) \\
\hline & & - Severity of symptom: positive association & \\
\hline & Day-care center & $\begin{array}{l}\text { - Parental history of atopy, but no maternal history of asthma: } \\
\text { inverse association with asthma }\end{array}$ & 6) \\
\hline & & - Maternal history of asthma: no apparent protective effect & \\
\hline & Dog or cat & - 2 or more pets (dogs or cats) reduce allergic sensitization & 7) \\
\hline \multirow[t]{3}{*}{ Unfavorable } & Machine dishwashing & - More allergic disease than hand dishwashing & 8) \\
\hline & Antibiotics & $\begin{array}{l}\text { - Prenatal and post-natal exposure was associated with an } \\
\text { increased risk of asthma }\end{array}$ & 9) \\
\hline & Cesarean section & $\begin{array}{l}-52 \% \text { increased risk of asthma compared with spontaneously } \\
\text { vaginally delivered }\end{array}$ & 10) \\
\hline \multirow[t]{2}{*}{ Not associated } & Home cleanliness & - Not associated with a risk for asthma and allergies & 11) \\
\hline & Breast feeding & Controversial & 12) \\
\hline
\end{tabular}


이보다 Bifidobacteria와 Bacteroides 가 적은 반면 Clostridium difficile이 더 많이 군집하고, 분유 수유를 한 아이들은 모유 수유를 한 아이들에 비해 E coli, Clostridium difficile, Bacteroides, Lactobacilli가 더 많이 분포한다. 입원과 조산은 $\mathrm{Clos}^{-}$ tridium difficile이 점막에 군집하게 되는 위험도를 증가시키 며, 항생제의 사용은 Bifidobacteria와 Bacteroides의 군집 수 를 줄이며, 나이가 더 많은 형제와 같이 생활하는 영아의 경우 혼자 자란 영아보다 Bifidobacteria의 군집이 더 많다. ${ }^{13)}$

\section{알레르기 질환 발생에 미치는 미생물군의 영향}

일반적으로 건강한 사람들의 장에는 Bacteroidetes, Firmicutes, Proteobacteria, Actinobacteria를 포함한 4가지 문 (phylus)이 주로 상재하고 있다. 정상 상재균의 균형이 깨지게 되거나 미생물군의 다양성 감소가 알레르기 질환의 발생과 상 관관계가 있다. ${ }^{14)}$

소아의 아토피 피부염의 경우 피부에 존재하는 미생물군의 불균형, 특히 Staphylococcus aureus의 군집이 질병의 발생 과 중증도를 증가시킨다고 보고가 되었다. ${ }^{15)}$ 하지만 소아에 서 장내 세균의 다양성의 감소와 장내 Bacteroidetes와 Proteobacteria의 감소 또한 아토피 피부염의 발생과 관련되어 있어, 이것은 미생물군이 숙주와 상호작용을 하여 국소적인 면역반응을 일으킬 뿐만 아니라 전신적으로도 영향을 미칠 수 있음을 시사한다. ${ }^{16)}$ 폐와 기도 점막에도 비슷한 현상이 일 어나는데, 생후 1개월에 Streptococcus pneumoniae, Haemophilus influenzae, Moraxella catarrhalis 가 상기도 분비 물에서 동정된 소아는, Staphylococcus aureus가 동정되거나 병원균이 발견되지 않은 소아에 비해 4 5세의 연령에서 더 높은 기도과민 위험도를 보인다. ${ }^{17)}$ 또한 아토피와 천식이 있는 소아에서는 신생아 시기에서 장내 미생물군의 다양성 감소 를 보였으며, ${ }^{18)}$ 균 종의 변화로는 Bifidobacterium과 Faecalibacterium species의 감소와 Candida와 Rhodotorula의 증 가가 관찰되었다. ${ }^{19}$

\section{알레르기 발생에서 조절 $\mathrm{T}$ 세포의 역할}

$\mathrm{T}$ 세포 중 면역 조절자로서의 역할을 하는 세포를 조절 $\mathrm{T}$ 세포(regulatory T cell)라고 하고 일반적으로 CD4+, CD25+ 와 Foxp3+의 표현형을 가지게 된다. 조절 T 세포는 IL-2에 의 해서 Foxp3+의 발현이 증가되어 transforming growth factor $-\beta(\mathrm{TGF}-\beta)$ 와 interleukin 10(IL-10)과 같은 항염증 사이 토카인을 분비하게 되며 이를 통해 다양한 경로로 면역기능 을 조절한다.

조절 $\mathrm{T}$ 세포는 수지상 세포의 기능을 억제하며, ${ }^{20)} \mathrm{TGF}-\beta$ 와 IL-10을 생산하여 항원 특이적인 Th2 세포의 활성화를 차
단한다. ${ }^{21)}$ 또한 OX40-OX40L 상호작용을 통해 비만세포의 탈과립화를 억제하며, ${ }^{22)} \mathrm{IL}-10$ 의 작용을 통해 작용 T 세포(effector T cell)가 조직 내로 유입되는 것을 억제한다. ${ }^{23}$ 조절 T 세포는 B 세포에도 작용해서 항원 특이 $\mathrm{IgE}$ 를 생성하는 것을 억제하고 $\mathrm{IgG} 4$ 를 생성하도록 유도하며, ${ }^{24)} \mathrm{Th} 17$ 에 의해 매개되 는 호중구의 염증반응도 억제하는 역할을 하고 있다. ${ }^{25)}$

인간을 대상으로 한 연구에서도 알레르기 질환이 없는 사 람에서 알레르기 질환을 가진 사람에 비해 조절 $\mathrm{T}$ 세포 혹은 조절 $\mathrm{T}$ 세포 유래 항염증 사이토카인인 IL-10이 증가되어 있 는 반면, 알레르기 질환이 있는 사람에서는 IL-4를 분비하는 $\mathrm{Th} 2$ 세포가 증가되어 있음이 알려져 있다. ${ }^{26)}$

인체 내 미생물군의 변화가 면역병리현상을 일으키는 기전 미생물군이 신생아 시기의 면역체계에 영향을 주는 기전은 동물 실험을 통해 밝혀지고 있는데, 특히 조절 $\mathrm{T}$ 세포를 유도 하여 면역 관용을 얻는 결과가 주로 보고되고 있다. 난알부 민(ovalbumin)으로 유도한 마우스 천식 모델에서 신생아 시 기에 vancomycin에 노출을 시켰을 때 장내 미생물군의 다양 성이 감소한다. 특히 Bacteroidetes가 거의 관찰되지 않고, 장 조직에서는 $\mathrm{CD} 4+, \mathrm{CD} 25+$ 와 Foxp3+의 표현형을 가진 조절 T 세포가 감소하였다. ${ }^{27)}$ 무균(germ-free) 마우스를 난알부민으 로 감작시키면 상재균이 존재하는 경우에 비해 $\mathrm{Th} 2$ 연관 사이 토카인과 $\mathrm{IgE}$ 수치가 기도에서 증가됨이 관찰된다. ${ }^{28)} \mathrm{Bacte}$ roides fragillis 에서 생산되는 다당류(polysaccharide)는 점막 과의 상호작용을 통해 전신적인 CD4+ T 세포의 결핍과 Th1/ $\mathrm{Th} 2$ 불균형을 교정하여 면역 조절자로서 역할을 한다. ${ }^{29)}$ Clostridium strain 혼합물을 주어 마우스 장내에 군집이 되 면 장내 TGF- $\beta$ 수치가 높아지며, Foxp3+ 조절 $\mathrm{T}$ 세포가 증 가된다. ${ }^{30}$ 폐에서 생후 2 주 이내의 시기에 세균에 노출이 증가 되면, Bacteroidetes가 지배적인 미생물군 구성으로 변하게 되며, 이러한 변화는 Helios 음성 조절 $\mathrm{T}$ 세포의 발현을 유도 하여 programmed death ligand 1과의 상호작용을 통해 항원 에 대한 과민반응을 줄여준다. ${ }^{31)}$ 피부에서도 생후 2주 이내 상재균의 존재가 조절 $\mathrm{T}$ 세포가 형성되는데 필요하며, 이렇게 생성된 조절 $\mathrm{T}$ 세포는 항원에 대해 면역 관용을 형성하는데 중요한 역할을 한다. ${ }^{32)}$ 사람의 세포 배양 연구에서도 미생물 군이 조절 $\mathrm{T}$ 세포의 발생에 영향을 주는 결과를 보이는데, Lactobacillus reuteri와 Lactobacillus casei는 수지상세포와 의 상호작용을 통해 조절 $\mathrm{T}$ 세포의 분화를 유도한다. ${ }^{33)}$

이상을 요약해 보면, 조절 $\mathrm{T}$ 세포는 다양한 경로를 통해 면 역 세포에 작용하여 면역 조절에 중추적인 역할을 맡고 있으 나, 미생물군이 인체 성장의 특정 시기에 면역체계에 충분한 자극을 주지 못할 경우 조절 $\mathrm{T}$ 세포의 활성이 떨어지고 이로 


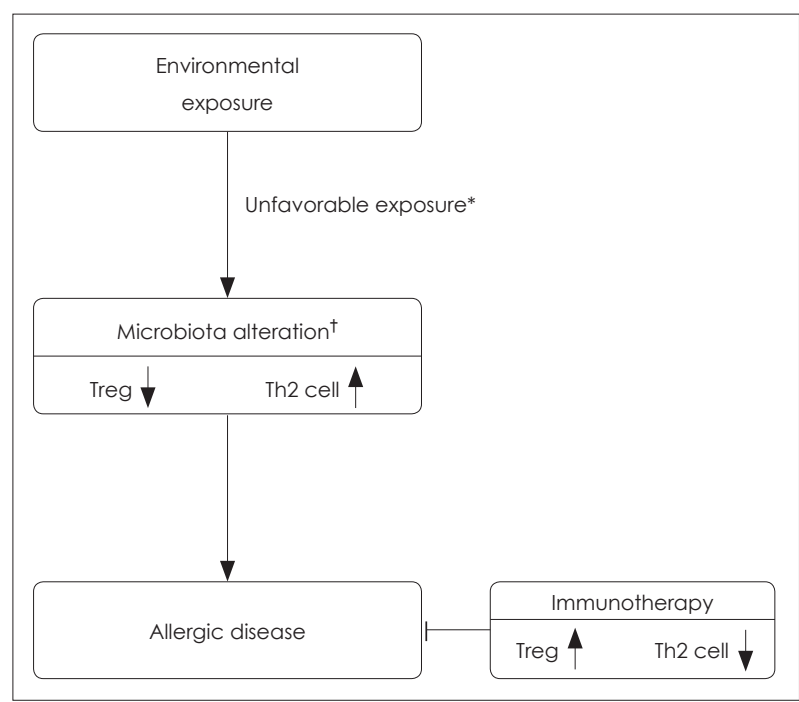

Fig. 1. Development of allergic disease in children. Microbiota is altered when it is affected by improper environmental conditions in the neonatal period. Due to altered microbiota, the activity of regulatory T cells declines and the levels of Th2-associated cytokines and $\mathrm{IgE}$ are increased. Immunotherapy induces immune tolerance by weakening the sensitization of the antigen and strengthening the function of regulatory T cells. *machine dishwashing, antibiotics, cesarean section, tunfavorable species, diversity $\downarrow$.

인해 Th2 염증반응이 억제되지 못하여 알레르기 질환이 발 생하게 된다고 생각하고 있다(Fig. 1).

\section{조절 $\mathrm{T}$ 세포 기능의 회복}

면역치료는 이른 생애에 부적절한 환경적 영향을 받아 이 에 의해 알레르기 질환이 발생하였더라 하더라도, 면역 관용 (immune tolerance)을 유도하여 항원에 대한 과민성을 약화 시키는 치료법으로, 알레르기 질환의 발병 기전에 따른 근본 적인 치료법이다. 면역치료 시 고용량의 항원을 주입하면 조절 $\mathrm{T}$ 세포가 유도되고, 이는 IL-10과 TGF- $\beta$ 를 생산하여 정상적 인 알레르기 염증반응을 억제하는 역할을 한다. 이에 따라, 항 원 특이 $\mathrm{IgG}$ 의 증가, 비강 내 분비물에 $\mathrm{IgG}, \mathrm{IgA}$ 의 증가, 치료 후기 $\operatorname{IgE}$ 감소, 호산구, 비만세포, 호염기구 및 림프구 등 염증 세포의 항원 반응성 감소가 나타난다. ${ }^{34)}$

\section{다양한 면역치료}

피하면역치료(subcutaneous immunotherapy)와 설하면역치료(sublingual immunotherapy)

현재 면역치료를 위해 피하면역치료와 설하면역치료가 대 표적으로 쓰이고 있으며 알레르기 비염을 가지고 있는 소아 환자를 대상으로 한 연구들을 Table 2에 정리하였다. 계절성 알레르기성 비염 환자를 대상으로 피하면역치료와 설하면역 치료의 효과에 대해 메타 분석 결과, 증상-약물 척도(symp- tom-medication score)와 삶의 질 척도는 비슷하였으나, 증 상 척도(symptom score)와 약물 척도(medication score)는 피 하면역치료에서 조금 더 나은 효과를 보였으나, 전신 부작용 은 더 흔하게 발생하였다. ${ }^{35)}$

\section{경피면역치료(epicutaneous immunotherapy)}

최근 피하면역치료와 설하면역치료 이외에도 다른 경로를 통해 항원을 주입하는 면역치료들이 개발되고 있다. 피부 패 치를 이용한 경피면역치료의 경우 피하주사나 설하 주입보다 항원을 주입하기 쉽고 간편하다는 장점이 있으며, 현재 음식 알레르기에 대한 면역치료제가 상품화되어 치료 효과가 보고 되고 있다. 땅콩 알레르기를 가진 74명의 소아 환자(4 25세) 에 대해 1 년간 경피면역치료를 시행하였을 때 $48 \%$ 에서 치료 성공률을 보였으며, 땅콩 특이적 $\mathrm{IgG} 4$ level이 증가하고 $\mathrm{IgG} 4 /$ $\operatorname{IgE}$ 비율이 감소하였다. $79.8 \%$ 에서 경도의 국소 피부 반응을 보였는데 1 명의 환자에서 피부반응으로 인해 치료를 중단한 경우가 발생하였다. ${ }^{49}$

36 개월 추적 관찰을 시행한 연구에서는 치료 시작 12 개월에 서는 $53.6 \%$ 에서의 치료에 반응을 보였지만, 36 개월 후에는 $83.3 \%$ 에서 치료에 반응을 보였으며 심각한 부작용은 발생하 지 않았다고 보고를 하였다. ${ }^{50)}$ 땅콩 알레르기 이외 우유 및 달 걀에서도 경피면역치료를 위한 치료제가 개발되어 임상시험 중에 있다.

\section{림프절 면역치료(intralymphatic immunotherapy)}

림프절 면역치료는 총 3회의 주입만으로 증상 개선이 있어, 장기간 정기적인 항원 주입이 필요하지 않다는 장점이 있다. 계 절성 알레르기 비염을 가진 청소년 환자 7명(15 24세)에게 초 음파 유도를 통해 서혜부 림프절에 4주 간격으로 3회(dose: 0.1, 0.2, $0.5 \mathrm{~mL}$ ) 항원을 주입을 한 경우 증상-약물 척도(symptom-medication score)에서 호전을 보였다. 부작용으로 주사 부위의 가려움증, 팽진(wheal), 압통 등이 있었으나 위약을 투 입한 군과 차이가 없었고, 특별한 치료 없이 자연 소실되었다. ${ }^{51)}$

계절성 알레르기를 가진 성인 7명을 대상으로 한 연구에서 도 비슷한 결과를 보였다. 위약 군에서는 치료 전후 차이를 보이지 않았으나, 림프절 면역치료 시행 군에서는 항원에 대한 비내 염증반응이 줄어들었고, 알레르기 비염의 증상이 개선되 었다. 항원 주입에 의한 심각한 부작용은 발생하지 않았다. ${ }^{52)}$

\section{피부 장벽의 손상, 알레르기 행진의 또 다른 시작}

피부 장벽의 손상은 아토피 피부염의 주된 발병 원인이다. 손상된 피부로부터 항원이 들어오면 선천면역반응(innate immune response)이 일어나고 항원제시세포(antigen pre- 
Immunologic Causes of Allergic Disease in Children I Kim JK, et al.

Table 2. Efficacy of SCIT and SLIT

\begin{tabular}{|c|c|c|c|c|c|c|c|c|}
\hline & Allergen & $\begin{array}{l}\text { Age } \\
\text { (year) }\end{array}$ & $\begin{array}{l}\text { Enrolled } \\
\text { (patient) }\end{array}$ & $\begin{array}{l}\text { Duration } \\
\text { (month) }\end{array}$ & $\begin{array}{l}\text { Cumulative } \\
\text { Dose }\end{array}$ & Effect & $\begin{array}{c}\text { Adverse } \\
\text { effect (patient) }\end{array}$ & Reference \\
\hline \multirow[t]{4}{*}{$\overline{\mathrm{SCIT}}$} & $\begin{array}{l}\text { Mixed grass } \\
\text { pollens }\end{array}$ & $6-14$ & 205 & 36 & $\begin{array}{l}2000 \text { SQ units/ } \\
6 \text { week }\end{array}$ & $\begin{array}{l}\text { Symptom score } \\
\text { improvement, } \\
\text { prevention of } \\
\text { asthma development }\end{array}$ & $\begin{array}{l}\text { Not } \\
\text { mentioned }\end{array}$ & 36) \\
\hline & Alternaria & $5-18$ & 50 & 36 & $\begin{array}{l}5000 \mathrm{TU} / \\
4-6 \text { week }\end{array}$ & $\begin{array}{l}\text { Symptom } \\
\text { medications score } \\
63.5 \% \text { decreased } \\
\text { than placebo }\end{array}$ & $\begin{array}{l}\text { Edema (4), } \\
\text { headache (1), } \\
\text { facial } \\
\text { flushing (1) }\end{array}$ & 37) \\
\hline & $\begin{array}{l}\text { Mixed grass } \\
\text { pollens }\end{array}$ & $3-16$ & 53 & 27 & $6000 \mathrm{TU}$ & $\begin{array}{l}\text { Symptom- } \\
\text { medication score } \\
\text { improvement }\end{array}$ & $\begin{array}{l}\text { Not } \\
\text { mentioned }\end{array}$ & 38) \\
\hline & All & $\begin{array}{l}\text { Mean } \\
37\end{array}$ & 118754 & 36 & Not mentioned & $\begin{array}{l}\text { Prevention of } \\
\text { asthma } \\
\text { development }\end{array}$ & $\begin{array}{l}\text { Not } \\
\text { mentioned }\end{array}$ & 39) \\
\hline \multirow[t]{7}{*}{ SLIT } & HDM & $5-12$ & 69 & 6 & $12 \mathrm{mg}$ & Positive & 0 & 40) \\
\hline & $\begin{array}{l}\text { Mixed grass } \\
\text { pollens }\end{array}$ & $6-12$ & 161 & 36 & $2625 \mathrm{kAU}$ & Positive & $\begin{array}{l}\text { Oral } \\
\text { itching (17), } \\
\text { urticaria (1) }\end{array}$ & 41) \\
\hline & $\begin{array}{l}\text { Mixed grass } \\
\text { pollens }\end{array}$ & $3-14$ & 97 & 32 & $\begin{array}{l}\text { Pangramin } \\
\mathrm{SLIT}^{\circledR} ; 0.5 \mu \mathrm{g}, \\
3 \text { times/week }\end{array}$ & $\begin{array}{l}\text { Symptom- } \\
\text { medication score } \\
77.3 \% \text { relived than } \\
\text { placebo }\end{array}$ & $\begin{array}{l}\text { SLIT }(49 \%) \\
\text { Placebo } \\
(27 \%)\end{array}$ & 42) \\
\hline & HDM & $6-18$ & 251 & 24 & $\begin{array}{l}700 \mathrm{BU}, \\
\text { twice/week }\end{array}$ & Not effective & Itching (14) & 43) \\
\hline & HDM & $12-64$ & 946 & 12 & $\begin{array}{l}\text { SQ HDM } \\
\text { SLIT tablet } \\
\text { (10000 jAU) daily }\end{array}$ & $\begin{array}{l}\text { Improved rhinitis } \\
\text { score }\end{array}$ & $\begin{array}{l}\text { Serious allergic } \\
\text { event (10) }\end{array}$ & 44) \\
\hline & $\begin{array}{l}\text { Mixed grass } \\
\text { pollens }\end{array}$ & $5-14$ & 153 & 36 & $\begin{array}{l}\text { Major allergen } \\
0.5 \mu g \text { daily } \\
\text { 5/week }\end{array}$ & $\begin{array}{l}\text { Prevention of } \\
\text { asthma } \\
\text { development }\end{array}$ & $\begin{array}{l}\text { Not } \\
\text { mentioned }\end{array}$ & 45) \\
\hline & All & $5-17$ & 216 & 36 & $\begin{array}{l}480 \mu g \\
\text { for HDM }\end{array}$ & $\begin{array}{l}\text { Improved } \\
\text { symptom than } \\
\text { drug group, } \\
\text { prevention of } \\
\text { asthma } \\
\text { development }\end{array}$ & $\begin{array}{l}\text { Not } \\
\text { mentioned }\end{array}$ & 46) \\
\hline \multirow[t]{2}{*}{$\begin{array}{l}\text { SCIT VS. } \\
\text { SLIT }\end{array}$} & HDM & $5-10$ & $\begin{array}{c}48 \\
\text { (SCIT: 16, } \\
\text { SLIT: 16) }\end{array}$ & 12 & $\begin{array}{l}\text { SCIT: } 111 \mu \mathrm{g} \\
\text { SLIT: } 295.5 \mu \mathrm{g}\end{array}$ & Both effective & $\begin{array}{l}\text { SCIT: } \\
\text { systemic } \\
\text { reaction (2), } \\
\text { SLIT: } 0\end{array}$ & 47) \\
\hline & HDM & $6-13$ & $\begin{array}{c}33 \\
\text { (SCIT: 11, } \\
\text { SLIT: 10) }\end{array}$ & 12 & $\begin{array}{l}\text { SCIT: } 43770 \text { TU } \\
\text { SLIT: } 173733 \text { TU }\end{array}$ & $\begin{array}{l}\text { Both effective on } \\
\text { rhinitis symptoms } \\
\text { (SLIT: no statically } \\
\text { significance) }\end{array}$ & $\begin{array}{l}\text { SCIT: local } \\
\text { injection (2), } \\
\text { SLIT: oral } \\
\text { itching (3) }\end{array}$ & 48) \\
\hline
\end{tabular}

Pangramin SLIT ${ }^{\circledast}$ (ALK-SCHERAX, Hamburg, Germany). SCIT: subcutaneous immunotherapy, SLIT: sublingual immunotherapy, SQ: standardised quality, HDM: house dust mite

senting cell)가 자극되어, $\mathrm{T}$ 세포의 증폭 및 재분배가 일어난 다. 이런 면역반응은 피부에 국한된 아토피 피부염을 일으킬 뿐만 아니라 전신적으로 퍼져 알레르기 행진을 일으키게 된 다. 위생 가설과 더불어 알레르기 행진을 일으키는 또 하나의 유력한 가설인 피부 장벽의 손상에 대해 알아보고 그에 따른 치료법을 알아보았다.

\section{피부 장벽 손상과 아토피 피부염}

표피는 기저층(stratum basale), 유극층(stratum spinosum), 과립층(stratum granulosum), 각질층(stratum corneum)의 4 개의 명확히 구분되는 층이 있다. 각질층은 전통적으로 벽돌 과 회 반죽 모형으로 설명되는데, 각질세포들이 지질이 풍부 한 세포외 기질에 끼워져 층을 이루고 있는 구조이다. 각질층 은 항균, 항산화, 보습, 피부감각 등의 기능을 가지고 피부 장 
벽으로서의 역할을 하고 있는데, 아토피 피부염 환자에서는 이러한 피부 장벽의 손상이 발견된다. ${ }^{53)}$

Filament-aggregating protein은 각질층을 구성하는 주요 단백 구조물로, FLG 유전자의 변이는 가장 잘 알려진 아토피 피부염의 유전적 소인이다. $\mathrm{FLG}$ 의 결핍 시 각질층의 피부 장 벽으로서의 기능이 떨어져 아토피 피부염이 잘 발생할 뿐만 아니라, 항원에 대한 감작(sensitization)이 증가되어 천식과 알레르기 질환의 발병률도 높아진다. ${ }^{54)}$ 그 외에도 세포외 기 질에서의 지질 대사 이상, 밀착연접(tight junction)의 손상, protease의 과발현, 피부 산성도(skin $\mathrm{pH}$ )의 유지 실패, 정상 상재균의 소실, 초-항원(super-antigen)에의 노출 등이 아토 피 피부염 발생에 영향을 준다. ${ }^{55)}$

\section{알레르기 행진에서의 아토피 피부염}

아토피 피부염으로 시작하여 음식 알레르기, 천식, 알레르 기 비염이 발생하는 기전은 표피에 존재하는 알레르기 항원 이나 세균이 손상된 피부 장벽으로부터 들어와 toll-like receptor와 같은 형태인식수용체(pattern recognition receptor) 를 통해 랑게르한스 세포(langerhan's cell)를 자극하여 시작 된다. 항원에 의해 자극된 항원표출세포(antigen presenting cell)는 IL-25, thymic stromal lymphopoietin(TSLP), $\mathrm{IL}-33$ 과 같은 선천성 사이토카인을 분비하여 Th2 반응을 유 도한다.

IL-25는 naïve T 세포에 직접 작용하여 Th2 세포로의 분화
를 유발하며, IL-33과 함께 group 2 innate lymphoid cell을 활성화하여 IL-5, IL-13을 분비한다. ${ }^{56)}$ 또한, IL-33은 TSLP$\mathrm{DC}-\mathrm{OX} 40 \mathrm{~L}$ 축을 활성화시켜 Th2 염증반응이 일어나서 유 지시키는 역할을 하며, 아토피 피부염 환자에서 피부뿐만 아 니라 부위 림프절(regional lymph node)에서도 검출이 되는 것으로 보아 전신적인 면역기능에 영향을 미친다고 추정된 다. ${ }^{57)} \mathrm{TSLP}$ 는 NK/T 세포 연관 경로를 통해 IL-13을 분비하 고 OX40L을 과발현하여 Th2 염증반응을 증폭시키는데, 피 부 장벽이 손상된 경우 각막세포(keratocyte)에서 분비된 TSLP가 전신적으로 순환하며 기도 과민반응을 야기하는 것 이 동물 실험으로 증명되었다. ${ }^{58}$

한편, 항원과 결합한 표피의 랑게르한스 세포와 진피의 수지 상세포(dendritic cell)는 부위 림프절로 이동하여 Th2 염증 반응을 일으키며, B 세포에서 $\mathrm{IgE}$ 로 변환시킨다. 또한, 부위 림 프절에서 생성된 기억 $\mathrm{T}$ 세포는 이후 전신을 순환하며 다른 알 레르기 질환을 유발하게 된다. ${ }^{59)}$

\section{알레르기 행진 예방}

피부 장벽 손상에 의한 알레르기 행진은 아토피 피부염의 발생을 막는 일차적인 치료와 아토피 피부염이 발생한 후 이 차적으로 전신적인 알레르기 질환으로 발전하지 않도록 차단 하는 두 가지 방향으로 예방할 수 있다(Fig. 2)

신생아에서 아토피 피부염의 발생을 예방하는 가장 중요한 것은 피부 보습이다. 보습제의 사용은 경피 수분 손실(trans-

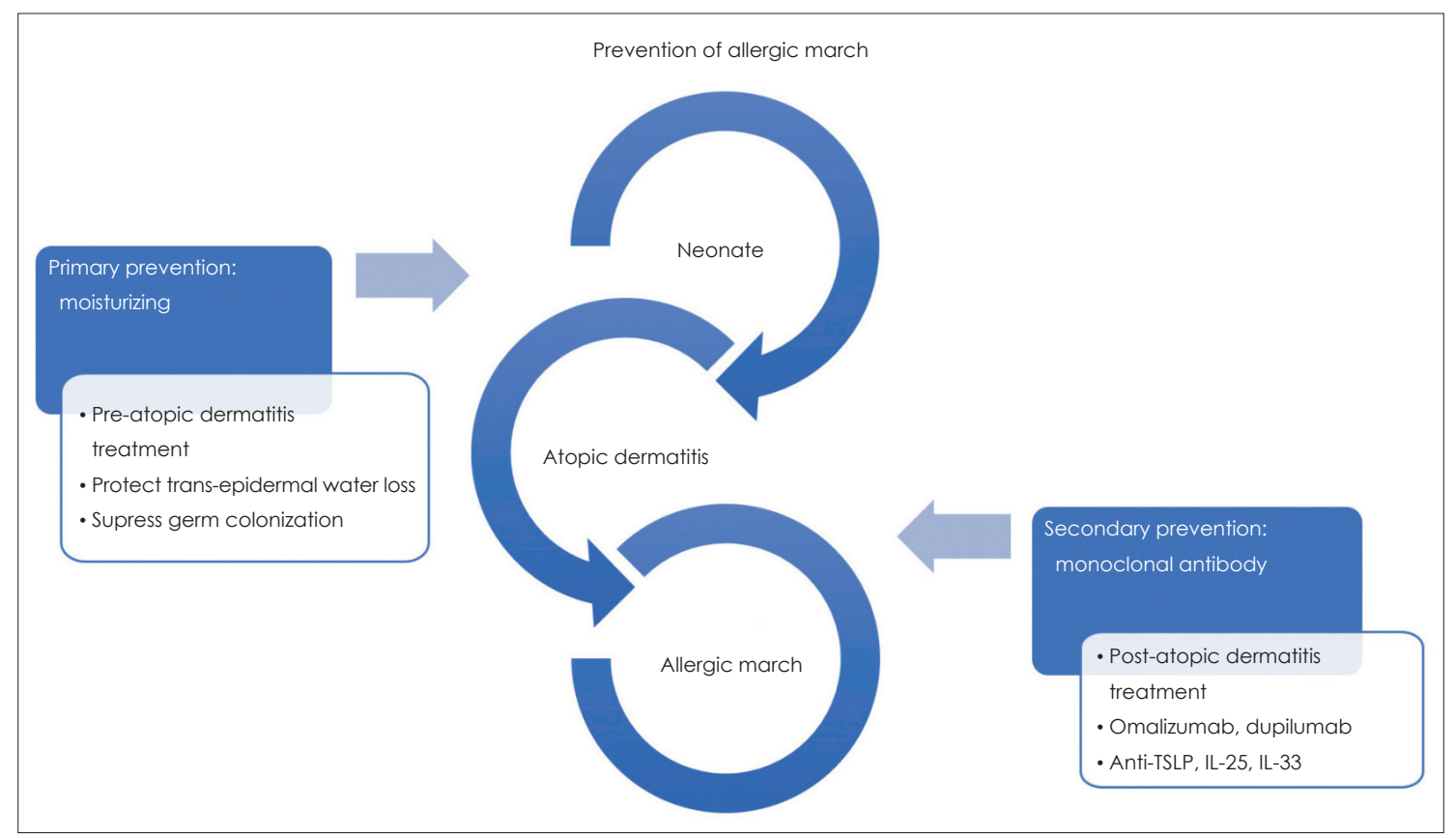

Fig. 2. Prevention of allergy march caused by skin barrier disruption. As a way to prevent allergy march caused by skin barrier disruption, there is primary prevention such as moisturizing treatment and potential secondary prevention such as monoclonal antibody treatment targeting type 2 inflammation. TSLP: thymic stromal lymphopoietin, IL: interleukin. 
epidermal water loss)을 막으며, 세균의 군집 형성을 억제한 다. ${ }^{60)} 124$ 명의 아토피 피부염 고위험군 신생아를 대상으로 시 행한 무작위 대조시험에서 생후 3주 동안 매일 전신에 보습제 를 바른 경우, 보습제를 사용하지 않은 경우에 비해 생후 6 개 월에 아토피 피부염의 발생이 $50 \%$ 감소하였다. ${ }^{61}$

아토피 피부염 발생 후 알레르기 행진을 막는 이차적 치료 에 대한 연구는 아직까지 많이 보고되지 않았다. 1 2세의 아 토피 피부염 환자에서 항히스타민제를 18 개월 동안 주었을 때 일부 그룹에서만 천식으로 진행이 줄어드는 효과를 보였 으며, ${ }^{62)} 3$ 18개월 아토피 피부염 환자에게 3년간 Pimecrolimus 크림을 바르도록 한 연구에서도 천식의 발생이 유의하게 줄어들지 않았다. ${ }^{63)}$

최근 알레르기 질환에 대한 단일클론항체(monoclonal antibody)를 이용한 치료에 대한 연구가 이루어지고 있다. Omalizumab은 $\mathrm{IgE}$ 에 대한 단일클론항체로 상용화되어 중등도 이 상의 알레르기성 천식 환자에서 사용되고 있으며, 천식 발작 의 빈도를 낮추는 장기간의 효과와 안정성이 입증되었다. ${ }^{64)}$

기존의 치료에 반응하지 않는 아토피 피부염 환자를 대상 으로 IL-4와 IL-13의 신호전달을 차단하는 Dupilumab(antiIL-4 $\alpha$ receptor monoclonal antibody)으로 치료를 한 임상 시험을 보면, Dupilumab는 위약에 비해 습진 부위, 중증도 정도, 삶의 질이 향상되었으나, 주사부위의 국소 반응과 결막 염은 대조군에 비해 더 많이 발생하였다. ${ }^{64)}$ Dupilumab은 흡 입 스테로이드 및 지속성 $\beta 2$ 작용제(long-acting $\beta 2$ agonist) 를 사용함에도 조절이 되지 않는 천식 환자에서도 폐 기능 회 복과 천식 발작을 줄이는 효과를 보인다. ${ }^{65)}$

선천성 사이토카인에 대한 단일클론항체 연구로는 antiTSLP 항체에 대한 연구가 가장 많이 진행되어 있다. 천식 환 자를 대상으로 한 임상 시험에서 anti-TSLP 항체는 혈액 및 가래에서 호산구를 감소시키고, 메타콜린에 대한 감수성을 줄이는 효과를 보였다. ${ }^{66)} \mathrm{IL}-25$ 및 IL-33에 대한 단일클론항 체도 현재 개발 및 임상시험 중에 있다.

아직 이러한 단일클론항체가 알레르기 행진으로의 진행을 차단하는 효과에 대한 연구는 없지만 상피세포 기원의 TSLP, IL-25, IL-33가 Th2 염증반응을 유도하는 것이 알레르기 행 진의 주된 기전으로 생각되며, 이러한 염증반응의 흐름을 차 단할 수 있다면 아토피 피부염으로부터 알레르기 행진을 막 는 이차적인 예방이 가능할 것으로 생각된다.

\section{결 론}

알레르기 질환은 소아에서부터 시작되어 성인까지 광범위 한 연령층에서 발생하는 질환이다. 소아에서의 알레르기 질
환에 대해 효과적인 치료를 하지 않는다면 연속적인 알레르 기 행진으로 나타난다. 본 종설에서는 알레르기 행진의 원인 가설을 두 가지 측면에서 알아보았다. 어린 시절 환경의 영향 에 의해 체내 미생물군의 구성이 변하게 되는데, 미생물군과 면역체계와의 상호 균형이 적절하지 못하게 되면 조절 $\mathrm{T}$ 세포 의 활성이 충분히 일어나지 않게 되어, 면역 조절 기능이 감소 하여 알레르기 질환이 발생하게 된다. 또한, 피부 장벽의 손상 에 의해 선천성 사이토카인이 활성화되고, Th2 염증반응이 증가하는 것도 알레르기 질환의 또 다른 발병 기전이라고 생 각된다. 이러한 발병 기전들을 고려하여 그 중간 전달 매개체 를 차단하는 면역치료를 더 연구한다면, 알레르기 질환을 예 방하고 치료하는 데 중요한 역할을 할 것으로 생각된다.

\section{ORCID}

Dae Woo Kim https://orcid.org/0000-0001-5166-3072

\section{REFERENCES}

1) Strachan DP. Hay fever, hygiene, and household size. BMJ 1989; 299(6710):1259-60.

2) Lynch SV, Wood RA, Boushey H, Bacharier LB, Bloomberg GR, Kattan M, et al. Effects of early-life exposure to allergens and bacteria on recurrent wheeze and atopy in urban children. J Allergy Clin Immunol 2014;134(3):593-601.e12.

3) Thorne PS, Kulhánková K, Yin M, Cohn R, Arbes Jr SJ, Zeldin DC. Endotoxin exposure is a risk factor for asthma: the national survey of endotoxin in United States housing. Am J Respir Crit Care Med 2005;172(11):1371-7.

4) Braun-Fahrländer C, Riedler J, Herz U, Eder W, Waser M, Grize L, et al. Environmental exposure to endotoxin and its relation to asthma in school-age children. N Engl J Med 2002;347(12):869-77.

5) Strachan DP, Ait-Khaled N, Foliaki S, Mallol J, Odhiambo J, Pearce $\mathrm{N}$, et al. Siblings, asthma, rhinoconjunctivitis and eczema: a worldwide perspective from the International Study of Asthma and Allergies in Childhood. Clin Exp Allergy 2015;45(1):126-36.

6) Celedon JC, Wright RJ, Litonjua AA, Sredl D, Ryan L, Weiss ST, et al. Day care attendance in early life, maternal history of asthma, and asthma at the age of 6 years. Am J Respir Crit Care Med 2003;167(9): 1239-43.

7) Ownby DR, Johnson CC, Peterson EL. Exposure to dogs and cats in the first year of life and risk of allergic sensitization at 6 to 7 years of age. JAMA 2002;288(8):963-72.

8) Hesselmar B, Hicke-Roberts A, Wennergren G. Allergy in children in hand versus machine dishwashing. Pediatrics 2015;135(3):e590-e7.

9) Metsälä J, Lundqvist A, Virta LJ, Kaila M, Gissler M, Virtanen SM. Prenatal and post-natal exposure to antibiotics and risk of asthma in childhood. Clin Exp Allergy 2015;45(1):137-45.

10) Tollånes MC, Moster D, Daltveit AK, Irgens LM. Cesarean section and risk of severe childhood asthma: a population-based cohort study. J Pediatr 2008;153(1):112-6.

11) Weber J, Illi S, Nowak D, Schierl R, Holst O, Von Mutius E, et al. Asthma and the hygiene hypothesis. Does cleanliness matter? Am J Respir Crit Care Med 2015;191(5):522-9.

12) Kim H, Sitarik AR, Woodcroft K, Johnson CC, Zoratti E. Birth mode, breastfeeding, pet exposure, and antibiotic use: associations with the gut microbiome and sensitization in children. Curr Allergy Asthma Rep 2019;19(4):22.

13) Penders J, Thijs C, Vink C, Stelma FF, Snijders B, Kummeling I, et 
al. Factors influencing the composition of the intestinal microbiota in early infancy. Pediatrics 2006;118(2):511-21.

14) Ege MJ, Mayer M, Normand AC, Genuneit J, Cookson WO, BraunFahrländer C, et al. Exposure to environmental microorganisms and childhood asthma. N Engl J Med 2011;364(8):701-9.

15) Kong HH, Oh J, Deming C, Conlan S, Grice EA, Beatson MA, et al. Temporal shifts in the skin microbiome associated with disease flares and treatment in children with atopic dermatitis. Genome Res 2012; 22(5):850-9.

16) Abrahamsson TR, Jakobsson HE, Andersson AF, Björkstén B, Engstrand L, Jenmalm MC. Low diversity of the gut microbiota in infants with atopic eczema. J Allergy Clin Immunol 2012;129(2): 434-40.

17) Bisgaard H, Hermansen MN, Bønnelykke K, Stokholm J, Baty F, Skytt NL, et al. Association of bacteria and viruses with wheezy episodes in young children: prospective birth cohort study. BMJ 2010;341:c4978.

18) Bisgaard H, Li N, Bonnelykke K, Chawes BL, Skov T, PaludanMüller G, et al. Reduced diversity of the intestinal microbiota during infancy is associated with increased risk of allergic disease at school age. J Allergy Clin Immunol 2011;128(3):646-52.e1-e5.

19) Fujimura KE, Sitarik AR, Havstad S, Lin DL, Levan S, Fadrosh D, et al. Neonatal gut microbiota associates with childhood multisensitized atopy and T cell differentiation. Nat Med 2016;22(10):1187-91.

20) Wing K, Onishi Y, Prieto-Martin P, Yamaguchi T, Miyara M, Fehervari Z, et al. CTLA-4 control over Foxp3+ regulatory T cell function. Science 2008;322(5899):271-5.

21) Jutel M, Akdis M, Budak F, Aebischer-Casaulta C, Wrzyszcz M, Blaser K, et al. IL-10 and TGF-beta cooperate in the regulatory T cell response to mucosal allergens in normal immunity and specific immunotherapy. Eur J Immunol 2003;33(5):1205-14.

22) Gri G, Piconese S, Frossi B, Manfroi V, Merluzzi S, Tripodo C, et al. $\mathrm{CD} 4+\mathrm{CD} 25+$ regulatory $\mathrm{T}$ cells suppress mast cell degranulation and allergic responses through OX40-OX40L interaction. Immunity 2008;29(5):771-81.

23) Ring S, Schäfer SC, Mahnke K, Lehr HA, Enk AH. CD4+ CD25+ regulatory $\mathrm{T}$ cells suppress contact hypersensitivity reactions by blocking influx of effector T cells into inflamed tissue. Eur J Immunol 2006;36(11):2981-92.

24) Meiler F, Klunker S, Zimmermann M, Akdis CA, Akdis M. Distinct regulation of $\mathrm{IgE}, \mathrm{IgG} 4$ and $\mathrm{IgA}$ by $\mathrm{T}$ regulatory cells and toll-like receptors. Allergy 2008;63(11):1455-63.

25) Jaffar Z, Ferrini ME, Girtsman TA, Roberts K. Antigen-specific Treg regulate Th17-mediated lung neutrophilic inflammation, B-cell recruitment and polymeric IgA and IgM levels in the airways. Eur J Immunol 2009;39(12):3307-14

26) Akdis M, Verhagen J, Taylor A, Karamloo F, Karagiannidis C, Crameri $\mathrm{R}$, et al. Immune responses in healthy and allergic individuals are characterized by a fine balance between allergen-specific $\mathrm{T}$ regulatory 1 and T helper 2 cells. J Exp Med 2004;199(11):1567-75.

27) Russell SL, Gold MJ, Hartmann M, Willing BP, Thorson L, Wlodarska $\mathrm{M}$, et al. Early life antibiotic-driven changes in microbiota enhance susceptibility to allergic asthma. EMBO Rep 2012;13(5):440-7.

28) Herbst T, Sichelstiel A, Schär C, Yadava K, Bürki K, Cahenzli J, et al. Dysregulation of allergic airway inflammation in the absence of microbial colonization. Am J Respir Crit Care Med 2011;184(2):198205.

29) Mazmanian SK, Liu CH, Tzianabos AO, Kasper DL. An immunomodulatory molecule of symbiotic bacteria directs maturation of the host immune system. Cell 2005;122(1):107-18.

30) Atarashi K, Tanoue T, Shima T, Imaoka A, Kuwahara T, Momose Y, et al. Induction of colonic regulatory $\mathrm{T}$ cells by indigenous Clostridium species. Science 2011;331(6015):337-41.

31) Gollwitzer ES, Saglani S, Trompette A, Yadava K, Sherburn R,
McCoy KD, et al. Lung microbiota promotes tolerance to allergens in neonates via PD-L1. Nat Med 2014;20(6):642-7.

32) Scharschmidt TC, Vasquez KS, Truong HA, Gearty SV, Pauli ML, Nosbaum A, et al. A wave of regulatory T cells into neonatal skin mediates tolerance to commensal microbes. Immunity 2015;43(5): 1011-21.

33) Smits HH, Engering A, Van der Kleij D, De Jong EC, Schipper K, Van Capel TM, et al. Selective probiotic bacteria induce IL-10producing regulatory $\mathrm{T}$ cells in vitro by modulating dendritic cell function through dendritic cell-specific intercellular adhesion molecule 3-grabbing nonintegrin. J Allergy Clin Immunol 2005;115(6):1260-7.

34) Potter PC. Update on sublingual immunotherapy. Ann Allergy Asthma Immunol 2006;96(2 Suppl 1):S22-S5.

35) Dretzke J, Meadows A, Novielli N, Huissoon A, Fry-Smith A, Meads C. Subcutaneous and sublingual immunotherapy for seasonal allergic rhinitis: a systematic review and indirect comparison. J Allergy Clin Immunol 2013;131(5):1361-6.

36) Möller C, Dreborg S, Ferdousi HA, Halken S, Høst A, Jacobsen L, et al. Pollen immunotherapy reduces the development of asthma in children with seasonal rhinoconjunctivitis (the PAT-study). J Allergy Clin Immunol 2002;109(2):251-6.

37) Kuna P, Kaczmarek J, Kupczyk M. Efficacy and safety of immunotherapy for allergies to Alternaria alternata in children. J Allergy Clin Immunol 2011;127(2):502-8.e1-6.

38) Keskin O, Tuncer A, Adalioglu G, Sekerel BE, Saçkesen C, Kalayci $\mathrm{O}$. The effects of grass pollen allergoid immunotherapy on clinical and immunological parameters in children with allergic rhinitis. Pediatr Allergy Immunol 2006;17(6):396-407.

39) Schmitt J, Schwarz K, Stadler E, Wüstenberg EG. Allergy immunotherapy for allergic rhinitis effectively prevents asthma: Results from a large retrospective cohort study. J Allergy Clin Immunol 2015;136(6):1511-6.

40) Ippoliti F, De Santis W, Volterrani A, Lenti L, Canitano N, Lucarelli $\mathrm{S}$, et al. Immunomodulation during sublingual therapy in allergic children. Pediatr Allergy Immunol 2003;14(3):216-21.

41) Bufe A, Ziegler-Kirbach E, Stoeckmann E, Heidemann P, Gehlhar K, Holland-Letz T, et al. Efficacy of sublingual swallow immunotherapy in children with severe grass pollen allergic symptoms: a doubleblind placebo-controlled study. Allergy 2004;59(5):498-504

42) Rolinck-Werninghaus C, Wolf H, Liebke C, Baars JC, Lange J, Kopp $\mathrm{MV}$, et al. A prospective, randomized, double-blind, placebo-controlled multi-centre study on the efficacy and safety of sublingual immunotherapy (SLIT) in children with seasonal allergic rhinoconjunctivitis to grass pollen. Allergy 2004;59(12):1285-93.

43) De Bot CM, Moed H, Berger MY, Röder E, Hop WC, De Groot H, et al. Sublingual immunotherapy not effective in house dust miteallergic children in primary care. Pediatr Allergy Immunol 2012;23(2): 151-9.

44) Okubo K, Masuyama K, Imai T, Okamiya K, Stage BS, Seitzberg $\mathrm{D}$, et al. Efficacy and safety of the SQ house dust mite sublingual immunotherapy tablet in Japanese adults and adolescents with house dust mite-induced allergic rhinitis. J Allergy Clin Immunol 2016;139(6):1840-8.e10.

45) Novembre E, Galli E, Landi F, Caffarelli C, Pifferi M, De Marco E, et al. Coseasonal sublingual immunotherapy reduces the development of asthma in children with allergic rhinoconjunctivitis. J Allergy Clin Immunol 2004;114(4):851-7.

46) Marogna M, Tomassetti D, Bernasconi A, Colombo F, Massolo A, Businco AD, et al. Preventive effects of sublingual immunotherapy in childhood: an open randomized controlled study. Ann Allergy Asthma Immunol 2008;101(2):206-11.

47) Eifan AO, Akkoc T, Yildiz A, Keles S, Ozdemir C, Bahceciler NN, et al. Clinical efficacy and immunological mechanisms of sublingual and subcutaneous immunotherapy in asthmatic/rhinitis children 
sensitized to house dust mite: an open randomized controlled trial. Clin Exp Allergy 2010;40(6):922-32.

48) Yukselen A, Kendirli SG, Yilmaz M, Altintas DU, Karakoc GB. Effect of one-year subcutaneous and sublingual immunotherapy on clinical and laboratory parameters in children with rhinitis and asthma: a randomized, placebo-controlled, double-blind, doubledummy study. Int Arch Allergy Immunol 2012;157(3):288-98.

49) Jones SM, Sicherer SH, Burks AW, Leung DY, Lindblad RW, Dawson $\mathrm{P}$, et al. Epicutaneous immunotherapy for the treatment of peanut allergy in children and young adults. J Allergy Clin Immunol 2017; 139(4):1242-52.e9.

50) Shreffler WG, Nadeau KC, Leonard SA, Sussman GL, Sampson HA. Efficacy and safety of long-term epicutaneous immunotherapy (EPIT) treatment of peanut allergy with Viaskin ${ }^{\circledR}$ peanut: results of the twoyear extension of the VIPES phase IIb clinical trial. J Allergy Clin Immunol 2017;139(2):AB377.

51) Patterson AM, Bonny AE, Shiels WE, Erwin EA. Three-injection intralymphatic immunotherapy in adolescents and young adults with grass pollen rhinoconjunctivitis. Ann Allergy Asthma Immunol 2016;116(2):168-70.

52) Hylander T, Latif L, Petersson-Westin U, Cardell LO. Intralymphatic allergen-specific immunotherapy: an effective and safe alternative treatment route for pollen-induced allergic rhinitis. J Allergy Clin Immunol 2013;131(2):412-20.

53) Cork MJ, Danby SG, Vasilopoulos Y, Hadgraft J, Lane ME, Moustafa $\mathrm{M}$, et al. Epidermal barrier dysfunction in atopic dermatitis. J Invest Dermatol 2009;129(8):1892-908.

54) Irvine AD, McLean WH, Leung DY. Filaggrin mutations associated with skin and allergic diseases. N Engl J Med 2011;365(14):1315-27.

55) Czarnowicki T, Krueger JG, Guttman-Yassky E. Novel concepts of prevention and treatment of atopic dermatitis through barrier and immune manipulations with implications for the atopic march. J Allergy Clin Immunol 2017;139(6):1723-34.

56) Salimi M, Barlow JL, Saunders SP, Xue L, Gutowska-Owsiak D, Wang $\mathrm{X}$, et al. A role for IL-25 and IL-33-driven type-2 innate lymphoid cells in atopic dermatitis. J Exp Med 2013;210(13):2939-50.

57) Murakami-Satsutani N, Ito T, Nakanishi T, Inagaki N, Tanaka A,
Vien PT, et al. IL-33 promotes the induction and maintenance of Th2 immune responses by enhancing the function of OX40 ligand. Allergol Int 2014;63(3):443-55.

58) Demehri S, Morimoto M, Holtzman MJ, Kopan R. Skin-derived TSLP triggers progression from epidermal-barrier defects to asthma. PLoS Biol 2009;7(5):e1000067.

59) Dubrac S, Schmuth M, Ebner S. Atopic dermatitis: the role of Langerhans cells in disease pathogenesis. Immunol Cell Biol 2010;88(4):400-9.

60) Pabst RC, Starr KP, Qaiyumi S, Schwalbe RS, Gewolb IH. The effect of application of aquaphor on skin condition, fluid requirements, and bacterial colonization in very low birth weight infants. J Perinatol 1999;19(4):278-83.

61) Simpson EL, Chalmers JR, Hanifin JM, Thomas KS, Cork MJ, McLean WH, et al. Emollient enhancement of the skin barrier from birth offers effective atopic dermatitis prevention. J Allergy Clin Immunol 2014;134(4):818-23.

62) Warner JO. A double-blinded, randomized, placebo-controlled trial of cetirizine in preventing the onset of asthma in children with atopic dermatitis: 18 months' treatment and 18 months' posttreatment follow-up. J Allergy Clin Immunol 2001;108(6):929-37.

63) Schneider L, Hanifin J, Boguniewicz M, Eichenfield LF, Spergel JM, Dakovic R, et al. Study of the atopic march: development of atopic comorbidities. Pediatr Dermatol 2016;33(4):388-98.

64) Lai T, Wang S, Xu Z, Zhang C, Zhao Y, Hu Y, et al. Long-term efficacy and safety of omalizumab in patients with persistent uncontrolled allergic asthma: a systematic review and meta-analysis. Sci Rep 2015;5:8191.

65) Wenzel S, Castro M, Corren J, Maspero J, Wang L, Zhang B, et al. Dupilumab efficacy and safety in adults with uncontrolled persistent asthma despite use of medium-to-high-dose inhaled corticosteroids plus a long-acting $\beta 2$ agonist: a randomised double-blind placebocontrolled pivotal phase $2 \mathrm{~b}$ dose-ranging trial. Lancet 2016;388(10039): 31-44.

66) Gauvreau GM, O’Byrne PM, Boulet LP, Wang Y, Cockcroft D, Bigler $\mathrm{J}$, et al. Effects of an anti-TSLP antibody on allergen-induced asthmatic responses. N Engl J Med 2014;370(22):2102-10.

\section{정답 및 해설}

(4)

해 설 반전성 유두종은 비부비동의 양성 종양으로 골파괴 소견은 흔하지 않으며 직접적인 골침습보다는 압박괴사를 유발한다. 반 전성 유두종은 비부비동에서 발생하는 종양 중 $0.5 \sim 4 \%$ 를 차지하는 비교적 드문 종양이며, 주로 일측성으로 발생하지만 양측성도 약 $4.9 \%$ 로 보고된다. 과거 광범위 근치술이 보다 선호되었으나 최근에는 비내시경하 절제술이 수술의 표준으로 자리매김하게 되었다. 참고문헌: 대한이비인후과학회. 이비인후과학. 비과. 파주: 군자출판사;2018. p.537-40. 